\title{
Acid Mine Drainage Dynamics from a Paste Tailing Deposit: Effect of Sulfate Content on the Consistency and Chemical Stability after Storage
}

\author{
Eduardo Leiva ${ }^{1,2, *(\mathbb{D}, \text { María Cayazzo }}{ }^{1}$, Luis Dávila ${ }^{3}$, Mario Torres ${ }^{4}$ and Christian Ledezma ${ }^{3}$ \\ 1 Departamento de Química Inorgánica, Facultad de Química y de Farmacia, \\ Pontificia Universidad Católica de Chile, Avenida Vicuña Mackenna 4860, Macul, Santiago 7820436, Chile; \\ maria.cayazzo@usach.cl \\ 2 Departamento de Ingeniería Hidráulica y Ambiental, Pontificia Universidad Católica de Chile, \\ Avenida Vicuña Mackenna 4860, Macul, Santiago 7820436, Chile \\ 3 Departamento de Ingeniería Estructural y Geotécnica, Escuela de Ingeniería, \\ Pontificia Universidad Católica de Chile, Avenida Vicuña Mackenna 4860, Macul, Santiago 7820436, Chile; \\ luisdanilo_18@hotmail.com (L.D.); ledezma@ing.puc.cl (C.L.) \\ 4 Departmento de Ingeniería Eléctrica, Pontificia Universidad Católica de Chile, \\ Avenida Vicuña Macken-na 4860, Macul, Santiago 7820436, Chile; mario.torres@ing.puc.cl \\ * Correspondence: ealeiva@uc.cl; Tel.: +56-2-2354-7224
}

check for updates

Citation: Leiva, E.; Cayazzo, M.; Dávila, L.; Torres, M.; Ledezma, C. Acid Mine Drainage Dynamics from a Paste Tailing Deposit: Effect of Sulfate Content on the Consistency and Chemical Stability after Storage. Metals 2021, 11, 860. https://doi.org/ $10.3390 /$ met11060860

Academic Editors: Rahul Ram and Mark I. Pownceby

Received: 6 April 2021

Accepted: 12 May 2021

Published: 25 May 2021

Publisher's Note: MDPI stays neutral with regard to jurisdictional claims in published maps and institutional affiliations.

Copyright: (c) 2021 by the authors. Licensee MDPI, Basel, Switzerland. This article is an open access article distributed under the terms and conditions of the Creative Commons Attribution (CC BY) license (https:// creativecommons.org/licenses/by/ $4.0 /)$.

\begin{abstract}
Surface paste tailings' disposal has emerged recently as an optimal and efficient method to favor tailings' self-containment after being deposited into dams. This disposal method can improve the reuse of water and reduce the generation of acid mine drainage (AMD) and the release of leachates (e.g., acid and heavy metals). However, the implications of chemical factors or mixed-water chemistry in the stability of paste tailings over time are not clear. In this work, we evaluated the release of sulfate from tailing samples and the role of sulfate as a critical factor in the tailings' strength, consistency, and stability. Our results showed that the release of acid runoff with high sulfate load from the tailings is negligible. Leaching tests were performed for 180 days and did not show a significant release of sulfate, heavy metals, or acid waters. However, the presence of sulfate salts derived from the binders used in the pretreatment of the paste tailings shows an impact on the tailings' consistency. Undrained triaxial monotonic compression tests revealed low effective cohesion forces in the tailings samples. In addition, it was observed that, in tailings slurries prepared with varying concentrations of sulfate $(0,500$, and $1000 \mathrm{mg} / \mathrm{L})$, the slump test value dropped $\Delta-55 \%$ when the sulfate concentration increased from 0 to $1000 \mathrm{mg} / \mathrm{L}$. These results support the idea that the presence of sulfate within the tailings could be relevant for the paste consistency after storage. This knowledge will contribute to a better understanding of the critical chemical factors that affect the stability of paste tailings over time.
\end{abstract}

Keywords: sulfate; paste tailings; cohesive strength; tailings consistency; slump tests

\section{Introduction}

Tailings are mineral wastes of low economic value that result from the extraction and enrichment processes of certain/specific elements in mining. The management of large volumes of tailings derived from mining operations has long-term economic, social, and environmental impacts [1]. For this reason, the proper disposal of these wastes is a great challenge for the mining industry around the world. However, this is a complex task because tailings have chemically reactive components, such as sulfide minerals, coagulants, and/or flocculants, that can alter the physical and mechanical properties of the tailings as well as their physical/chemical stability over time, which may trigger the release of dangerous flows and serious environmental problems.

Traditionally, tailings are placed in storage dams to contain the waste. However, there is a severe risk of spillage in unconsolidated solid materials [2]. The sliding or displacement 
of material from the dam can release polluting elements, such as heavy metals, severely impacting the environment, especially natural water sources. During the last years, the use of more consolidated tailings based on low viscosity fluids has been explored $[3,4]$. These tailings are known as paste tailings and behave like a non-Newtonian fluid that promotes a consolidation process, improves the stability of the tailings pile, allows greater water recycling within the mining operation, and reduces groundwater infiltration $[5,6]$. Paste tailings are a mixture of solids and water, with low water drainage that remains as a compact mass with low deformation after its disposal $[7,8]$. This configuration eliminates or reduces the need for a retaining wall, which is characteristic of conventional tailings since the same tailing has self-containment due to its own agglomeration $[9,10]$. There is not a standard paste-tailing configuration, because its formation depends on the solids percentage and the type of minerals present in each mining operation. While the behavior of paste tailings in the pipeline concerning its rheology, geometry, and associated physical parameters have been studied extensively [11-16], tailings chemical factors that may influence the final configuration and the long-term behavior of the tailings have received less attention. Similarly, it has not yet been fully understood how their polluting potential changes under this new configuration.

Paste tailings are obtained with thickened tailings or grinding waste filtered to about $80 \%$ by weight. The binder and water are added to achieve the expected consistency and the desired rheological and resistance properties [12]. The mechanical and rheological properties of thickened tailings depend on the physical and mineralogical properties of mine tailings [17]. Factors such as cohesive strength, density, and solid percentage are decisive for the formation of tailings and their disposal in paste fillings $[18,19]$. On the other hand, the release of contaminants from the paste tailings will be critical in the long-term operation of tailings deposits based on the safe disposal process. In this way, the acid mine drainage (AMD) generation is the most important environmental challenge related to tailings storage.

AMD occurs when sulfide minerals are exposed to oxygen and water, which generate runoffs characterized by a low $\mathrm{pH}$ and high concentrations of sulfate and dissolved metal-loids [20-22] The AMD dynamics is a complex process that will depend on the characteristics of the mineral phases of the deposit and physical, chemical, and biological factors [20]. Based on this, the paste tailing has an environmental advantage by retaining moisture and remaining saturated, which reduces the potential for AMD generation [19]. Thus, the sulfide minerals in the paste deposit are not exposed to an oxidizing environment (in a proper management) and are less likely to produce AMD leachates [23].

Chemical factors can also influence the quality of tailings. Particularly, mixing-water chemistry can have a significant impact on the tailings' cohesive properties. The cohesive forces allow particle agglomeration and promote the formation of the paste. However, the agglomeration capacity can change over time, affecting the consistency and long-term stability. Despite the environmental relevance of paste-tailing dams, most research on paste tailings has been associated with cemented paste backfill (CPB), an engineered mixture of wet fine-process tailings used in mine structures. For example, in CPB, the sulfate can cause stability problems in structures caused by the acid-and-sulfate-attack phenomenon, generating expansive phases that cause physical damage due to material fractures [24-29]. On the contrary, there are few studies focused on the chemical stability of paste tailings after storage.

In this study, we explored the AMD dynamics of paste gold tailings and examined the impact of sulfate content on the consistency of tailings samples. These results may be relevant to develop adequate management procedures for thickened tailings considering monitoring and control of key chemical parameters. In addition, these findings of this study can improve our compression about these systems. 


\section{Materials and Methods}

\subsection{Site Description and Sampling}

Tailings samples derived from the Florida mine (Yamana Gold Inc., Santiago, Chile) were selected for resistance analysis and to evaluate the acid-mine drainage generation potential (Figure 1). The Florida mine is an underground gold-silver mine located $73 \mathrm{~km}$ south-southwest of Santiago in the locality of Alhue. The mine is located in Santiago's central valley, a mountainous area with moderate topography, narrow valleys, and high hills. Without considering its reserves, the potential resources of the mine are approximately $2.7 \mathrm{Mt}$ at $4.8 \mathrm{~g} / \mathrm{t} \mathrm{Au}, 37 \mathrm{~g} / \mathrm{t} \mathrm{Ag}$, and $1.16 \% \mathrm{Zn}$. The primary deposits of Florida Mine are based on stockwork and vein gold deposits. Specifically, andesitic tuffs and other volcaniclastic rocks of the upper cretaceous of the exploitation area contain gold and polymetallic mineralizations hosted by quartz veins and stockwork. The sulfide minerals in the deposit are dominated by phases of pyrite $\left(\mathrm{FeS}_{2}\right)$, sphalerite $\left.(\mathrm{Zn}, \mathrm{Fe}) \mathrm{S}\right)$ galena $(\mathrm{PbS})$, and chalcopyrite $\left(\mathrm{CuFeS}_{2}\right)$, while the main oxides are hematite $\left(\mathrm{Fe}_{2} \mathrm{O}_{3}\right)$ and magnetite $\left(\mathrm{Fe}_{3} \mathrm{O}_{4}\right)$ (Florida mine information). Additionally, hyperspectral analysis performed with Hy-logger3 technology reported the presence of carbonate phases, such as calcite $\left(\mathrm{CaCO}_{3}\right)$ and dolomite $\left(\mathrm{CaMg}\left(\mathrm{CO}_{3}\right)_{2}\right)$ (Florida mine information).

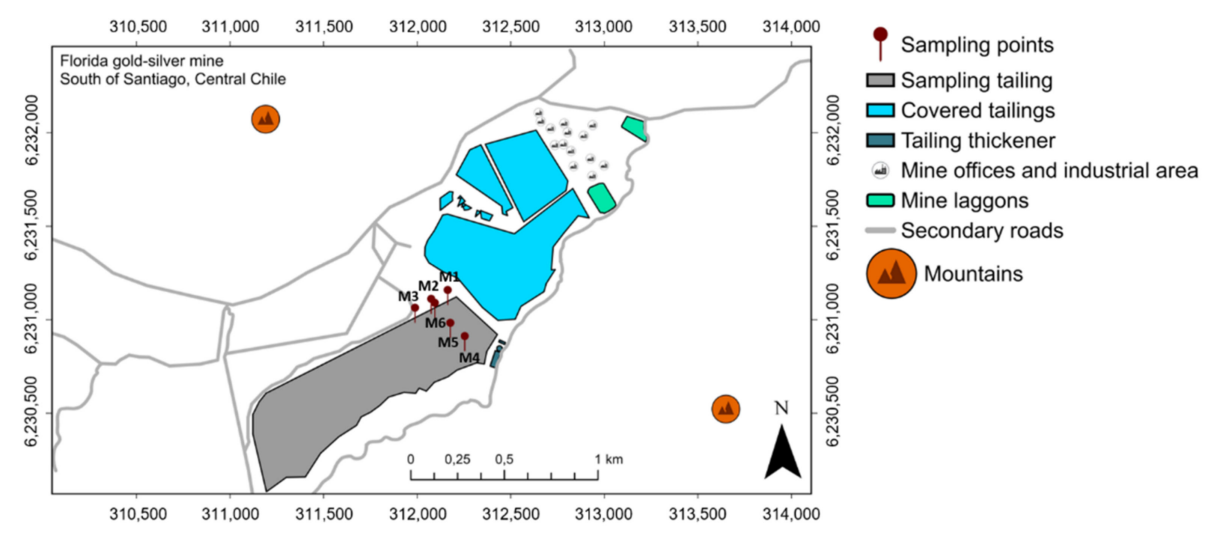

(a)

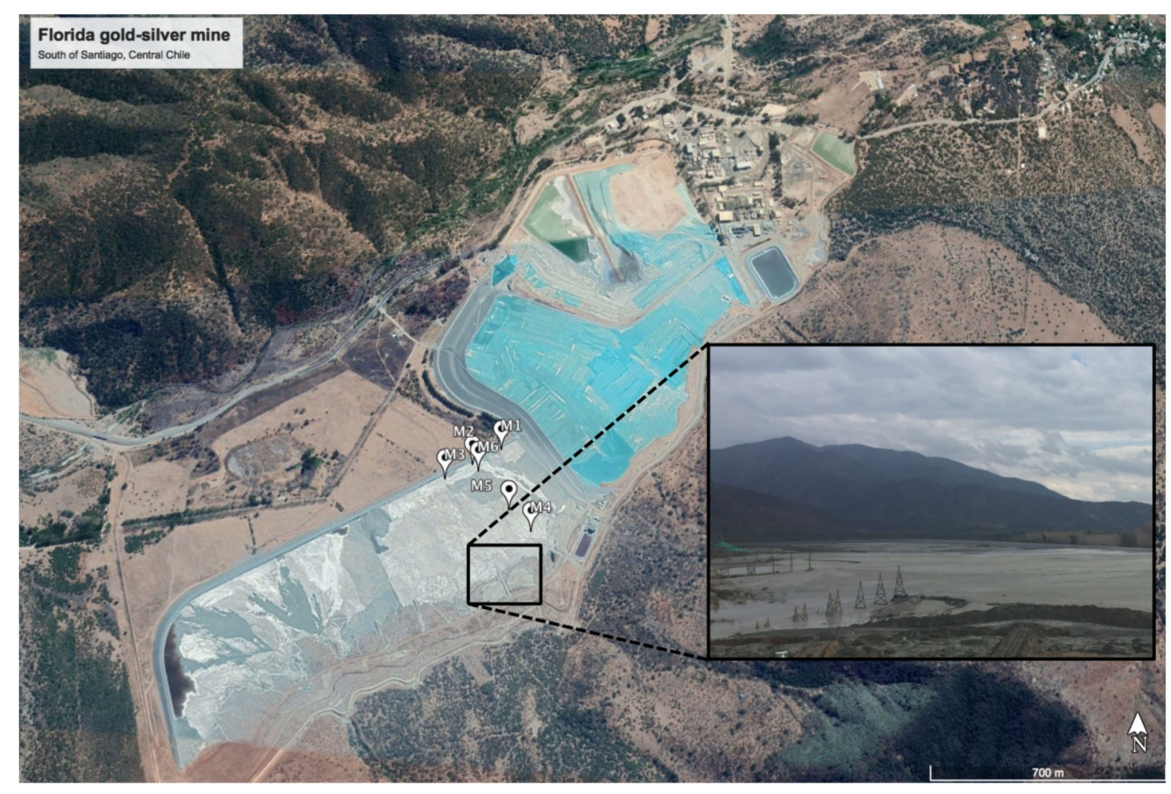

(b)

Figure 1. (a) Location of tailing sampling points in Florida Gold-Silver Mine, South of Santiago, Central Chile. (b) Paste tailings deposit area. 
Paste-tailing samples were collected from the tailings deposit area (Figure 1a,b). The sampling was carried out in two field campaigns during December 2017 and January 2018. For the analyses, solid surface samples were selected to evaluate the release of pollutants and acid-mine drainage generation. Surface samples were chosen for their higher oxygenation and potential exposure to water (AMD requirements). Specifically, the sampling was carried out in a straight line with three equidistant sampling points (M1, M2, and M3), crossed by a perpendicular line with three other sampling points (M4, M5, and M6) (Figure 1a). This sampling was performed to achieve an adequate evaluation of the tailings, considering sampling points from north to south and from east to west over the deposit area.

To the sampling, $1 \mathrm{~kg}$ of tailing samples was collected from the surface of the pastetailing deposit. Sampling considers paste samples from the first $15 \mathrm{~cm}$ of the tailings deposit. Samples were collected by using 1 L High-Density Polyethylene (HDPE) bottles ((Thermo Fisher Scientific, San Jose, CA, USA).). Once the samples were collected, they were stored and kept in the dark at $4{ }^{\circ} \mathrm{C}$ until they were processed and analyzed in the laboratory. On-site water analyses included temperature (PHC301, HACH), electrical conductivity (EC) (CDC401, HACH), and pH (PHC301, HACH) (Hq40d Multi, HACH, Loveland, CO, USA).

\subsection{Tailings Analysis}

The paste tailings have a specific gravity of between 2.70 and $2.81 \mathrm{~g} / \mathrm{mL}$. After thickening, the paste tailings with a solids concentration of $70.2 \pm 2.2 \%$, a slump of $26.3 \pm 2.5 \mathrm{~mm}$, and an average yield stress values of $55.5 \pm 10.9 \mathrm{~Pa}$ are pumped into the tailings dam. After storage, several conditions (humidity \%, solids concentration, etc.) can change, influencing the consistency of the paste tailings over time. To evaluate this, each tailing sample was subject to physical and chemical analysis. Before the analysis of the samples, they were decanted and mixed to ensure homogeneity. Humidity percentage and texture were determined for all samples. The tailing texture was determined by the hydrometer method [30].

Each paste-tailing sample was analyzed for paste $\mathrm{pH}$ (PHC301, Hach, Loveland, CO, USA) and electrical conductivity (CDC401, Hach, Loveland, CO, USA) (Hq40d Multi, Hach, Loveland, CO, USA). Moreover, $\mathrm{pH}$ and electrical conductivity (EC) measurements were made with $20 \mathrm{~g}$ of wet tailings $\left(40^{\circ} \mathrm{C}\right.$, sieved $\left.<2 \mathrm{~mm}\right)$, using adapted protocols from ISO 10390:1994 (E) (pH) and ISO 11265:1994 (EC). The pH was measured in the original solution paste with a liquid/solid ratio (L/S) between 1.80 and 1.86 (adapted protocol from ISO 10390:1994 (E)), and the electrical conductivity was measured in a saturated paste extract (EC) from the original paste suspension (adapted protocol from ISO 11265:1994). Sulfate was analyzed by spectrophotometry in the saturated water (paste) after centrifugation of $50 \mathrm{~g}$ of tailing sample at $6000 \mathrm{rpm}$.

The tailing samples were also used for compositional analysis in solid phases. Tailing samples were dried at $60{ }^{\circ} \mathrm{C}$ for two days, and then they were sieved ( $\leq 2 \mathrm{~mm}$ ) for homogenization. Tailings samples were digested according to EPA 3050B digestion method [31]. For each digestion procedure, $1 \mathrm{~g}$ of dried sediment was transferred into a digestion vessel. The digestion vessel was covered with a watch glass and was heated to $95{ }^{\circ} \mathrm{C} \pm 5{ }^{\circ} \mathrm{C}$ and refluxed for $15 \mathrm{~min}$. The digestate was filtered at $0.22 \mu \mathrm{m}$ and collected in a $100 \mathrm{~mL}$ volumetric flask. The filter and the residue were placed back in the vessel and another $5 \mathrm{~mL}$ of $\mathrm{HCl} 37 \%$ was added and refluxed for $5 \mathrm{~min}$ until the filter was dissolved. The digestate was newly filtered at $0.22 \mu \mathrm{m}$ and collected in the same $100 \mathrm{~mL}$ volumetric flask. When the filtrate cooled, it was diluted to volume. Heavy metals, cations, and sulfur concentrations in the digestion and saturated waters were determined calorimetrically by spectrometry (Spectrophotometer DR/2010, Hach, Loveland, CO, USA) and by Inductively Coupled Plasma Optical Emission Spectrometry (ICP-OES) (PerkinElmer Optima 7300 DV ICP_OES, Shelton, CT, USA). 


\subsection{Scanning Electron Microscopy}

The surface of dry tailings samples $\left(40^{\circ} \mathrm{C}\right.$, sieved $\left.<2 \mathrm{~mm}\right)$ were characterized through Scanning Electron Microscopy with Energy Dispersive Spectroscopy (SEM-EDS). Tailing samples were fixed with $2 \%$ glutaraldehyde solution in a sodium cacodylate buffer $(0.2 \mathrm{M}$, $\mathrm{pH} 7.2$, at $4{ }^{\circ} \mathrm{C}$ ) and coated with carbon in a desktop sputterer (Desk V; Denton Vacuum, Moorestown, NJ, USA). The observation was performed in a scanning electron microscope (JSM-IT300LV; JEOL Ltd., Tokyo, Japan) equipped with an Oxford EDX AZtec detector (Oxford Instruments, High Wycombe, UK). For SEM-EDS analysis, each sample was analyzed at 4 points, and the detection results were averaged.

\subsection{Leaching Tests: Humidity Cells}

The leaching tests were based on the humidity cell protocol developed by Sobek et al. [32] and adapted by ASTM [33], Lawrence [34], Price [35], and White and Lapakko [36]. Fourcylinder acrylic cells of an internal diameter of $12 \mathrm{~cm}$ and a height of $45 \mathrm{~cm}$ were used in the experiment. All cells were loaded with approximately $1 \mathrm{~kg}$ of fine $(<2 \mathrm{~mm})$ dry paste-tailing sample and subjected to aeration cycles. Weekly aeration cycles were with 3 days of dry air (controlled by silica gel) and 3 days of humidified air (air supplied at $1-10 \mathrm{~L} / \mathrm{min}, \mathrm{ASTM}$, 1996) and flushed with $500 \mathrm{~mL}$ de ultrapure water on the final (7th) day of the cycle. The ultrapure water was allowed to get in contact with the tailing sample for approximately $1 \mathrm{~h}$ before being drained into a collection flask (as Price [35]). The experiment was developed over a period of 24 weeks.

Leachate geochemical parameters were measured in each operation cycle. Leachate $\mathrm{pH}$ and leachate EC were measured immediately after the samples were collected by using a $\mathrm{pH}$ electrode (PHC301, Hach, Loveland, CO, USA) and a conductivity meter (CDC401, Hach, Loveland, CO, USA) (Hq40d Multi, Hach, Loveland, CO, USA). Filtered and non-acidified leachate subsamples were used for sulfate analysis. All the leachate samples were stored in the dark at $4{ }^{\circ} \mathrm{C}$ until processing and analysis. The leached sulfate concentrations were measured by using spectrophotometry (DR 3900 Spectrophotometer, Hach, Loveland, CO, USA). Laboratory temperature was continuously monitored and varied between 20 and $25^{\circ} \mathrm{C}$.

\subsection{Monotonic Compression Tests}

Paste-tailing samples were subjected to undrained triaxial monotonic compression tests, using a computer-controlled mechanical press having a maximum loading capacity of $25 \mathrm{kN}$ and a displacement rate of $0.001 \mathrm{~mm} / \mathrm{min}$. The data acquisition was carried out in a GEODATALOG 6000 Series unit (30WF6016, Wykeham Farrance Inc., Slough, England). The compression test was used to estimate the cohesion of the tailing as a measure of the resistance of the paste to deformation. For the determination of the cohesion, the Mohr-Coulomb failure criterion was used Equation (1):

$$
\tau \mathrm{f}=\mathrm{c}+\sigma \tan \varphi
$$

where $\tau f$ is the shear stress acting on the failure plane, $\mathrm{c}$ the cohesion, $\sigma$ the normal stress acting on the failure plane, and $\varphi$ the internal friction angle.

The monotonic tests were performed in cylindrical columns of $100 \mathrm{~mm}$ in height and $50 \mathrm{~mm}$ in diameter with a selected paste-tailing sample (M4) from Florida gold mining. Sample preparation for cylindrical columns was achieved by drying the sample at $60^{\circ} \mathrm{C}$ and then adding water to the soil particles to form a paste with a density of $70 \%$ solid particles. Subsequently, the paste was incorporated into a tube of polyvinyl chloride (PVC) with a diameter lower than the cylindrical columns. This tube has holes to allow the water to escape and generate uniformity in the paste. The sample was dried for 20 days, and then the column was carved.

For the analysis, a monotone triaxial equipment with a chamber with vertical deformation, pore pressure, back pressure, and chamber pressure transducers were used. The deformation transducer has a maximum measurement capacity of $25 \mathrm{~mm}$, and the pressure 
transducers have a limit pressure of $1000 \mathrm{kPa}$. The test was carried out with a deformation rate of $1 \% / \mathrm{h}(\sim 15 \% / \mathrm{min})$ [37]. The confining pressures $\left(\sigma_{3}\right)$ tested were $18,36,40,72,80$, and $160 \mathrm{kPa}$. Pore pressures $(\mathrm{pw})$ were measured during the deformation test. In the tests, the effective confining pressure was obtained as $\sigma_{3}^{\prime}=\sigma_{3}-$ pw.

\subsection{Slump Tests}

Slump tests were used to determine the properties of paste tailings after deposition. Slump tests have been suggested as a good index test to access the yield stress [38,39]. The tests were carried out considering the paste density, the water retention, and the modified slump cone test. The paste density and the percentage of solids were determined by drying $200 \mathrm{~g}$ of paste tailings at $60^{\circ} \mathrm{C}$. The humidity percentage (water content) in the sample and the percentage of solids (solid concentration \%) were determined from the difference in mass between the wet sample and the dry sample. With this information, the slump test was performed. Thus, the amount of sulfate-free water and water with sulfate necessary to reach a desired consistency of paste were added to the dry mass of tailings replicating the original solid contents: 88.6\% (M1), 87.0\% (M2), 85.7\% (M3), 90.1\% (M4), 83.6\% (M5), and $86.2 \%$ (M6). Initially, paste tailings in the thickener reach average solids percentages of $70.2 \% \pm 1.5 \%$ before disposal; however, the solid contents increased after disposal, reaching values between 83.6 and $90.1 \%$ for surface paste samples. This can result from water loss in surface areas (consolidation) or high evaporation rates in the area (desiccation), increasing solids content.

The determination of the slump provides information about the consistency of the material for transport and its potential for self-deposition and cohesion. The slump is the fall or reduction of the height of a material when it is released from a cone-shaped slip mould. The standard slump tests are useful to determine the consistency of the tailings paste due to its simplicity. Slump tests were performed by using an acrylic (adapted material) conical mold of $150 \mathrm{~mm}$ high, $25 \mathrm{~mm}$ of top radius, and $50 \mathrm{~mm}$ of base radius, following the procedure described by Clayton et al. [38]. The slump height was defined as the difference between the initial and the final height (Hi-Hf) of the paste sample after the conical mold was removed. The slump height was measured after a settling time of $10 \mathrm{~min}$. For the analysis, the original paste tailings samples were dried at $60{ }^{\circ} \mathrm{C}$, and, subsequently, new uniform paste tailings were prepared by using distilled water with varying concentrations of sulfate $(0,500$, and $1000 \mathrm{mg} / \mathrm{L})$ to evaluate the impact of sulfate on the slump height and in the cohesive strength. The paste was prepared with the same percentage of solids as the original sample to evaluate the changes in the slump height associated with different sulfate content and not due to variations in the water content of the samples.

\subsection{Quality Assurance/Quality Control (QA/QC)}

Quality assurance/quality control (QA/QC) procedures were performed for all analyzes and experiments to obtain reliable and accurate results. All the instruments used in this study were calibrated before using certified reference standards or analytical grade synthetic standards and following instrument guidelines. In addition, the chemicals used in this work were analytical grade, and all the solutions used in this study were carried out with Milli-Q water. Likewise, all laboratory and field materials were neatly cleaned and rinsed with Milli-Q water.

Analytical measurements (e.g., pH and EC) in the field and laboratory were verified by performing replicate analyzes (duplicate). Sample blanks were included during each analytical run. Furthermore, the accuracy and precision of the measurements of metals, anions, and cations were checked and compared against synthetic standard samples of known concentration. QC of each piece of equipment used in this study was accomplished by the periodic monitoring of the results. The monotone triaxial equipment was checked continuously to ensure the accuracy of the results (monotonic tests). 


\subsection{Statistical Analysis}

All statistical data of the slump test were analyzed by using statistical tools associated with GraphPad Prism 8.0.1 (GraphPad Software, La Jolla, CA, USA). Differences in slump test value between the added sulfate concentrations were analyzed by comparing the means and using the non-parametric two-tailed Kruskal-Wallis test, followed by Dunn's test for multiple comparisons. The critical level for rejection of the null hypothesis was $p<0.05$.

\section{Results and Discussion}

\subsection{General Properties of Tailings}

The properties of the tailings samples are shown in Table 1 . The $\mathrm{pH}$ values (paste $\mathrm{pH}$ ) at sites M1, M2, M3, M4, M5, and M6 fluctuates between 7.8 and 9.1, which indicates the dominance of alkaline values. The M6 sample has the most alkaline $\mathrm{pH}$ ( $\mathrm{pH}$ 9.1), which is opposite to mining operations with a high pyrite content, where acidic $\mathrm{pHs}$ are dominant $[40,41]$. These data suggest that the tailing samples have a low acid-generation capacity or that their neutralizing potential is high. However, the use of basic chemical reagents during the thickening and flocculation processes can influence the resulting $\mathrm{pH}$ of paste tailings, generating neutral-alkaline wastes. In addition, in paste tailings dams, an important volume of the solution remains in the tailings, influencing the resulting $\mathrm{pH}$ after disposal.

Table 1. General properties of surface tailings collected from Yamana Gold mine and control site.

\begin{tabular}{|c|c|c|c|c|c|c|}
\hline \multirow{2}{*}{$\begin{array}{l}\text { Tailing } \\
\text { Sample }\end{array}$} & \multirow{2}{*}{$\mathrm{pH}$} & \multirow{2}{*}{$\begin{array}{c}\mathrm{EC} \\
\left(\mathrm{mS} \mathrm{cm}^{-1}\right)\end{array}$} & \multirow{2}{*}{$\begin{array}{c}\text { Humidity } \\
(\%)\end{array}$} & \multicolumn{3}{|c|}{ Texture } \\
\hline & & & & Clay (\%) & Silt (\%) & Sand (\%) \\
\hline M1 & $7.9 \pm 0.1$ & $2.0 \pm 0.2$ & $11.6 \pm 0.3$ & $19.0 \pm 0.0$ & $53.3 \pm 1.2$ & $27.7 \pm 1.2$ \\
\hline M2 & $8.8 \pm 0.1$ & $1.5 \pm 0.2$ & $13.1 \pm 0.1$ & $18.3 \pm 1.2$ & $55.0 \pm 1.0$ & $26.7 \pm 0.6$ \\
\hline M3 & $7.8 \pm 0.2$ & $1.2 \pm 0.1$ & $14.8 \pm 0.8$ & $18.0 \pm 1.0$ & $54.3 \pm 2.1$ & $27.7 \pm 1.2$ \\
\hline M4 & $7.8 \pm 0.2$ & $11.4 \pm 0.8$ & $9.6 \pm 0.3$ & $16.3 \pm 1.2$ & $52.3 \pm 1.5$ & $31.4 \pm 2.5$ \\
\hline M5 & $7.8 \pm 0.2$ & $1.8 \pm 0.2$ & $16.6 \pm 0.3$ & $19.0 \pm 2.8$ & $59.0 \pm 8.5$ & $22.0 \pm 11.3$ \\
\hline M6 & $9.1 \pm 0.2$ & $1.2 \pm 0.1$ & $14.5 \pm 0.9$ & $19.0 \pm 2.8$ & $59.0 \pm 7.1$ & $22.0 \pm 9.9$ \\
\hline
\end{tabular}

* The data correspond to average values \pm their standard deviation $(n=3)$.

The EC paste values at these sites were significantly high. The highest EC value was obtained for the M4 sample ( 11.4 ms/cm), while an average EC value of $1.2 \mathrm{mS} / \mathrm{cm}$ was obtained for the M3 sample. The importance of these high conductivity values is that high concentrations of ions, such as sulfate, can negatively impact nearby ecosystems by contaminating surface water and groundwater resources, limiting their availability for different purposes. It has been reported that conductivity values greater than $4 \mathrm{dS} / \mathrm{cm}$ are associated with seed germination inhibition and the reduction of plants' growth rates, which adversely affects crops yield [42]. In addition, Ji et al. [43] found that electrostatic repulsion among the negatively charged solid particles can be reduced through the increase in tailings' salinity and the negatively charged polymer flocculants that promote the polymer bridging interactions. Therefore, an explanation for the high EC of paste tailings is that, during mining operations, the chemical reagents binder favors the flocculation and enhances the settling of mineral tailings. Likewise, after the tailings deposition, hazardous wastes that can release elements such as $\mathrm{Cu}, \mathrm{Cr}, \mathrm{Cd}, \mathrm{Pb}, \mathrm{Sb}, \mathrm{Ni}, \mathrm{Zn}$, and As can affect the surrounding environment and cause environmental degradation, as it has been observed in gold-mine tailings [44]. In addition, the high salt load (sulfate) could also be detrimental to the tailings' physical stability by promoting internal post-deposition fractures, which has been proved to be a concrete structure degradation mechanism [45,46]. Nevertheless, this has not been thoroughly studied for paste tailings.

Tailings samples were classified as silty loam (Table 1). On the other hand, humidity percent for all samples (after storage) were found between $9.6 \%$ and $16.6 \%$, which indicates that the solids concentration increased in relation to the paste tailings prior to storage in the tailing dam. 


\subsection{Chemical Analysis of Tailings}

The chemical composition of paste tailings samples is shown in Table 2. The results showed that total concentrations of $\mathrm{S}, \mathrm{Al}, \mathrm{Mn}, \mathrm{Fe}, \mathrm{Zn}$, and $\mathrm{Pb}$ are quite high. The content of Fe and Mn were higher at site M4, M5, and M6. The S content was higher in samples M4 and M6. Moreover, tailings samples from sites M4 and M6 contained the highest total Zn and $\mathrm{Pb}$ concentrations. Average values of $\mathrm{Zn}$ and $\mathrm{Pb}$ were $9385 \mathrm{ppm}(\mathrm{Zn})$ and $5841 \mathrm{ppm}$ $(\mathrm{Pb})$ at the $\mathrm{M} 4$ site and $8218 \mathrm{ppm}(\mathrm{Zn})$ and $4610 \mathrm{ppm}(\mathrm{Pb})$ at the M6 site. In the same way, other toxic metals (loids) such as arsenic (As) and cadmium (Cd) were found but in lower concentrations in all tailings samples.

Table 2. Chemical composition of tailings samples.

\begin{tabular}{|c|c|c|c|c|c|c|}
\hline & \multirow[b]{2}{*}{ M1 } & \multirow[b]{2}{*}{ M2 } & \multicolumn{4}{|c|}{ Tailing Sample } \\
\hline & & & M3 & M4 & M5 & M6 \\
\hline & \multicolumn{6}{|c|}{ Major and minor elements (\% wt) } \\
\hline $\mathrm{Fe}$ & 2.9 & 2.9 & 2.9 & 3.7 & 3.9 & 3.7 \\
\hline $\mathrm{Al}$ & 1.3 & 1.3 & 1.4 & 1.4 & 1.4 & 1.6 \\
\hline $\mathrm{Mn}$ & 1.8 & 2.0 & 2.1 & 3.3 & 2.9 & 2.2 \\
\hline $\mathrm{Ca}$ & 2.5 & 2.5 & 2.5 & 3.0 & 3.7 & 3.1 \\
\hline \multirow[t]{2}{*}{ S } & 1.6 & 1.6 & 1.5 & 1.9 & 1.1 & 1.8 \\
\hline & \multicolumn{6}{|c|}{ Trace elements (ppm) } \\
\hline $\mathrm{Zn}$ & 6440 & 6227 & 6439 & 9385 & 3441 & 8218 \\
\hline $\mathrm{Pb}$ & 3309 & 3194 & 3132 & 5841 & 2172 & 4610 \\
\hline $\mathrm{Cu}$ & 399 & 471 & 379 & 532 & 372 & 595 \\
\hline As & ND & ND & ND & ND & 33 & 51 \\
\hline $\mathrm{Cd}$ & $\mathrm{ND}$ & ND & 27 & 85 & ND & 44 \\
\hline $\mathrm{Ag}$ & $\mathrm{ND}$ & ND & $\mathrm{ND}$ & $\mathrm{ND}$ & $\mathrm{ND}$ & $\mathrm{ND}$ \\
\hline
\end{tabular}

A potential advantage of paste tailings can be the reduction of leachates generation, which occurs due to the paste's capability to retain moisture [47]. However, this will depend on the proper management of the tailings dams and several other factors, including the characteristics of the paste formed, climatic conditions, and the dam maintenance. However, the mobilization of heavy metals and other polluting elements could be influenced by a reduction in the physical stability of the tailings as a result of chemical elements present in the pore water that may attack the tailings paste internally. It has been observed that internal fractures can cause higher rates of evaporation in slurry tailings by reducing the water load and favoring the generation of leaching [48]. High evaporation rates can trigger a desaturation of the tailing paste, which can promote the entry of oxygen. If the tailings are highly sulfidic, the oxygen can promote the generation of AMD and the mobilization of heavy metals and sulfate and contaminate surface water and groundwater resources. Dold and Fondbote [49] observed that under high evaporation conditions, the tailings' surface could be enriched in metals via capillary transport, leading to the formation of highly soluble secondary minerals. For this reason, to evaluate the impact of these tailings, it is necessary to consider their behavior over time and the mobilization of the elements that can be potentially released.

The morphology and elemental composition of a representative tailing sample (M2) were determined by using Scanning Electron Microscopy (SEM) coupled to Energy Dispersive Spectrometry (EDS). Electron microscopy images showed mineralization with different sizes and irregular shapes in samples (Figure 2a). SEM images show a heterogeneous microstructure indicative of the variable degree of compaction. It is observed that some particles react with each other forming agglomerates or flaky shape layers, while others are seen as isolated particles. Despite this, it can be seen that the particles and agglomerates are small, between $2 \mathrm{um}$ and $5 \mathrm{um}$ in size. This can strongly influence the generation of AMD because tailings compaction can limit the oxygen diffusion into the 
tailing and, therefore, the potential oxidation of metal sulfides and acid runoff generation. EDX microanalysis revealed the presence of $\mathrm{O}, \mathrm{Si}, \mathrm{Fe}, \mathrm{Al}, \mathrm{Zn}$, and $\mathrm{S}$ signals on the surface of paste tailings (Figure 2b). Dold and Fontboté [49] indicate that in tailings with low grain sizes located in climates with high evaporation rates, the flow of water due to capillarity forces can produce metal enrichments on the surface of the tailings. Thus, metals released by AMD processes can be transferred to the top of the tailings. Although these conditions are in the tailings dam of the Florida Mine, the surface analyzes by EDX do not show an evident enrichment of metals (Figure 2b). Even so, the element signals in the EDX spectrum are correlated with chemical analyzes for major and minor elements in tailings samples (Table 1). The main elements found in the surface of the samples were $\mathrm{O}, \mathrm{Si}, \mathrm{Al}$, and $\mathrm{Fe}$. Other elements such as As, Au, and Ag were not identified. Enkhzaya et al. [50] found similar compositions in tailing samples collected on a small-scale gold-mining area in the Tov and Selenge province, Mongolia. Specifically, they found tailings samples enriched in $\mathrm{Si}, \mathrm{O}$, and $\mathrm{Al}$. Thus, compositional analyzes of paste tailings samples support the idea that the long-term stability of these deposits should be considered because changes in tailing's stability can lead to the release of potentially toxic elements and compounds.

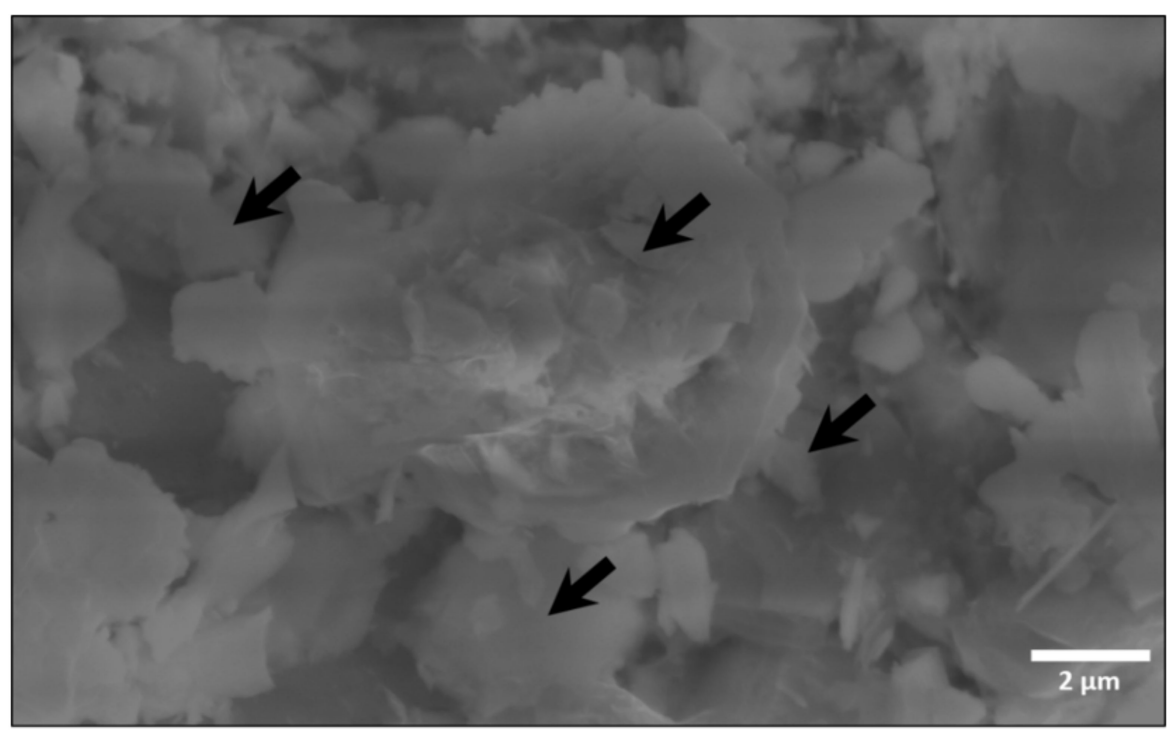

(a)

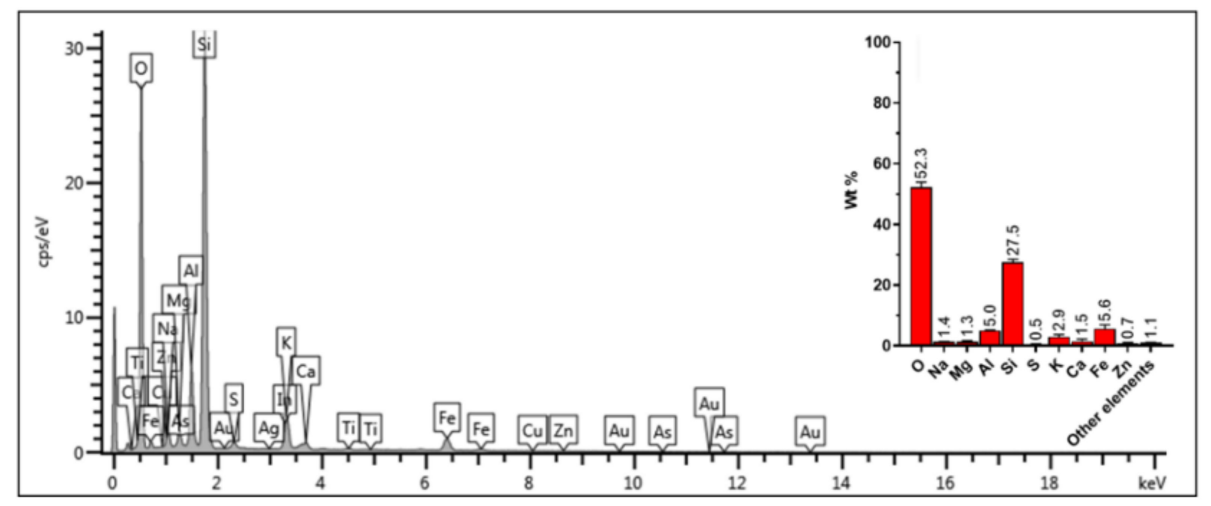

(b)

Figure 2. (a) Scanning electron micrographs of paste-tailing samples, carbon was used as a surface coating (arrows show the different sizes of tailings particles). (b) Energy-dispersive $X$-ray spectrum of paste-tailing samples. Intensity of $\mathrm{Al}, \mathrm{Si}, \mathrm{Fe}, \mathrm{S}$, and $\mathrm{Zn}$ emission lines are shown in the Energy Dispersive X-Ray Spectroscopy (EDX) spectrum. The images and EDX spectrum were obtained from a representative sample of the M2 site. Scale bar indicates $2 \mu \mathrm{m}$. 


\subsection{Leachates Generation Rates}

To determine the geochemical behavior of tailings samples over time, humidity cells were operated for 182 days. All of the tailings samples had similar geochemical compositions; however, to study AMD kinetics, the selection criteria were based on the total sulfur content. Thus, the samples with the highest sulfur content (M2, M4, and M6 with 1.6, 1.9, and $1.8 \% \mathrm{wt} \mathrm{S}$, respectively) were selected for leaching tests. Additionally, these samples also had higher heavy metal content.

The $\mathrm{pH}$ evolution in tailings leaching cells is shown in Figure 3a. The results were consistent with the paste $\mathrm{pH}$ data reported in Table 1. None of the tailings samples exhibited acidic leaching, indicating that the generation of acidic waters was negligible for surface tailings samples. Even more, the $\mathrm{pH}$ behavior was stable over time in a range of values between 7 and 9 and for a period of about 36 cycles (weeks). After the initial leach, the $\mathrm{pH}$ remains stable at neutral-alkaline values, consistent with the paste $\mathrm{pH}$ data reported in Table 1. For all cells, the $\mathrm{pH}$ values do not show significant changes during the operation, which rules out late acid generation processes. The reference sample (soil sample) showed similar behavior, with a $\mathrm{pH}$ between 6 and 8 . In this case, the low acidification in the reference sample can be explained by the lower easily oxidizable metal-bound sulfides content of the total sample.

Figure $3 \mathrm{~b}$ shows the EC in leachates released from the humidity cells. The initial EC values in leachates were similar to those observed for the paste EC. For cells M2, M4, and M6, the EC was high during the first two operating cycles (High EC leachates), reaching values greater than $5000 \mathrm{uS} / \mathrm{cm}$, and then the EC values of all cells rapidly decreased over 3 cycles, with an average value of less than $400 \mathrm{uS} / \mathrm{cm}$. In fact, from day 28 onwards, low EC leachates are observed. The EC then recovered over from cycle 3 (21 days) to cycle 36 (182 days), and it was between 910 and $55.6 \mathrm{uS} / \mathrm{cm}$. The sharp drop in the EC during the first cycles of operation indicates rapid solubilization of the ions present in the tailings paste water, which can be decisive in the generation of high salinity runoff. Although, the high ion load in leachates can also be influenced by the reagents used during the coagulation-flocculation process.

In relation to the runoff acidity, the neutral-alkaline $\mathrm{pH}$ of leachates suggests that acid generation processes are not significant after the tailings have been deposited. No acid leachates were observed after the initial cycles, which confirmed that tailings have a low potential for acid generation mediated by oxidation processes despite the sulfur content. The oxidation of sulfide minerals favors the release of a runoff with a high sulfate content and a marked increase in EC during humidity cell operation. Humidity cells are useful to know how fast acid-producing reactions occur, such as pyrite oxidation, the most common sulfide mineral [51-53]. Sulfide minerals are stable under reducing conditions, but in the presence of water and oxygen, these minerals can be oxidized and release acid water with a high load of sulfate and metal ions [54,55]. Nevertheless, after acidic release, several minerals such as carbonates, hydroxides, and silicates can neutralize the protons produced [55]. The absence of acid leachates can result from the high content of neutralizing minerals in paste-tailing samples. In fact, phases of Calcite $\left(\mathrm{CaCO}_{3}\right)$ and Dolomite $\left(\mathrm{CaMg}\left(\mathrm{CO}_{3}\right)_{2}\right)$ present in the base minerals of the deposit can promote continuous neutralization processes. Hence, neutralization reactions could consume the acids produced and maintain the $\mathrm{pH}$ at neutral-alkaline values. In addition, the high silicon content in tailings samples could explain the release of neutral-alkaline leachates. However, it cannot be ruled out that chemical reagents may have a significant influence on the geochemistry of released leachates. 


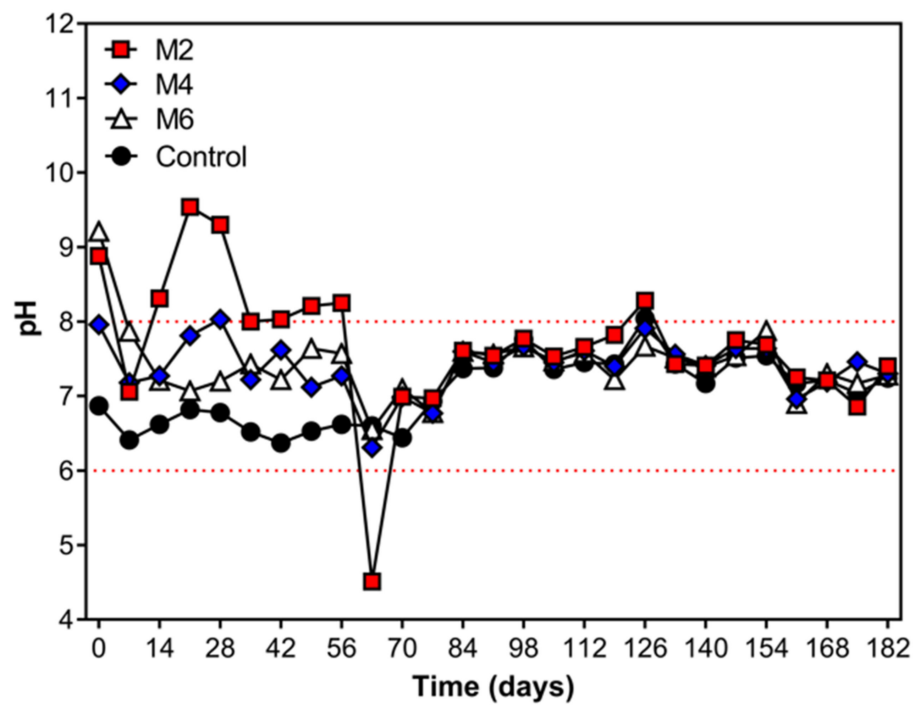

(a)

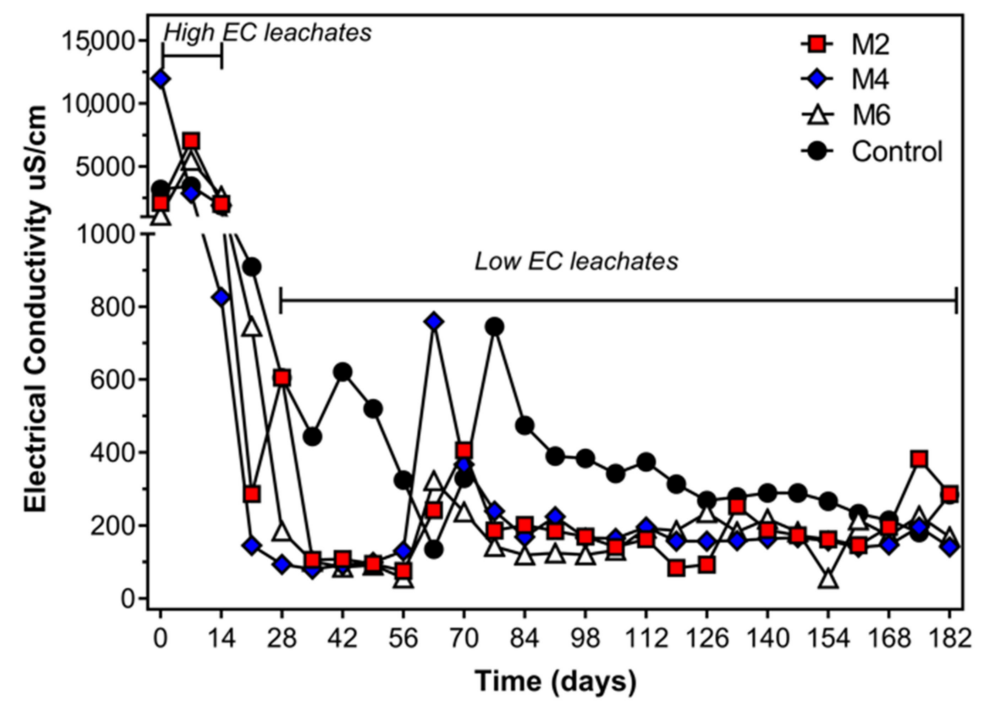

(b)

Figure 3. $\mathrm{pH}$ (a) and electrical conductivity (b) evolution over time in the humidity cells tests for paste-tailing samples.

The time evolution of sulfate is shown in Figure 4. All samples generated leachates with similar sulfate concentrations after the second cycle. During the first two cycles, cells M2 and M6 reached maximum sulfate values of 1020 and $330 \mathrm{mg} / \mathrm{L}$, respectively, while cell M4 reached $2900 \mathrm{mg} / \mathrm{L}$ (High sulfate leachates). On cycle 2, the rate of sulfate release decreases progressively to values below $100 \mathrm{mg} / \mathrm{L}$ for all tailing samples However, by cycle 9 (63 days), the M4 sample showed a slight increase in sulfate release (360 mg/L), but the same phenomenon was observed for the control cell. Therefore, it may be a consequence of some alteration in the operation of the cells, which may have favored a preferential route of elusion within the cells that was not used in the initial cycles and thus produce a late dissolution process. Despite this, after cycle 3, the rate of sulfate release was indistinguishable from the control standard cell. It is evident from the data that aeration in tailings samples does not accelerate sulfate release processes. On the contrary, it is the solubilization processes that would support the initial release of sulfate. Before disposal, the paste tailings have high concentrations of sulfate in the thickener, reaching average values of $3854.5 \pm 1757.6 \mathrm{mg} / \mathrm{L}$. Interestingly, these sulfate concentrations were 
similar to the cumulative values of sulfate released by the tailings samples during the operation of humidity cells. This strongly suggests that the sulfate concentrations released in the leachates are associated with the mobilization of the sulfate present in the tailings. Furthermore, acid mine drainage generation processes would have a lower impact, which is supported by the low acidity of the leachates.

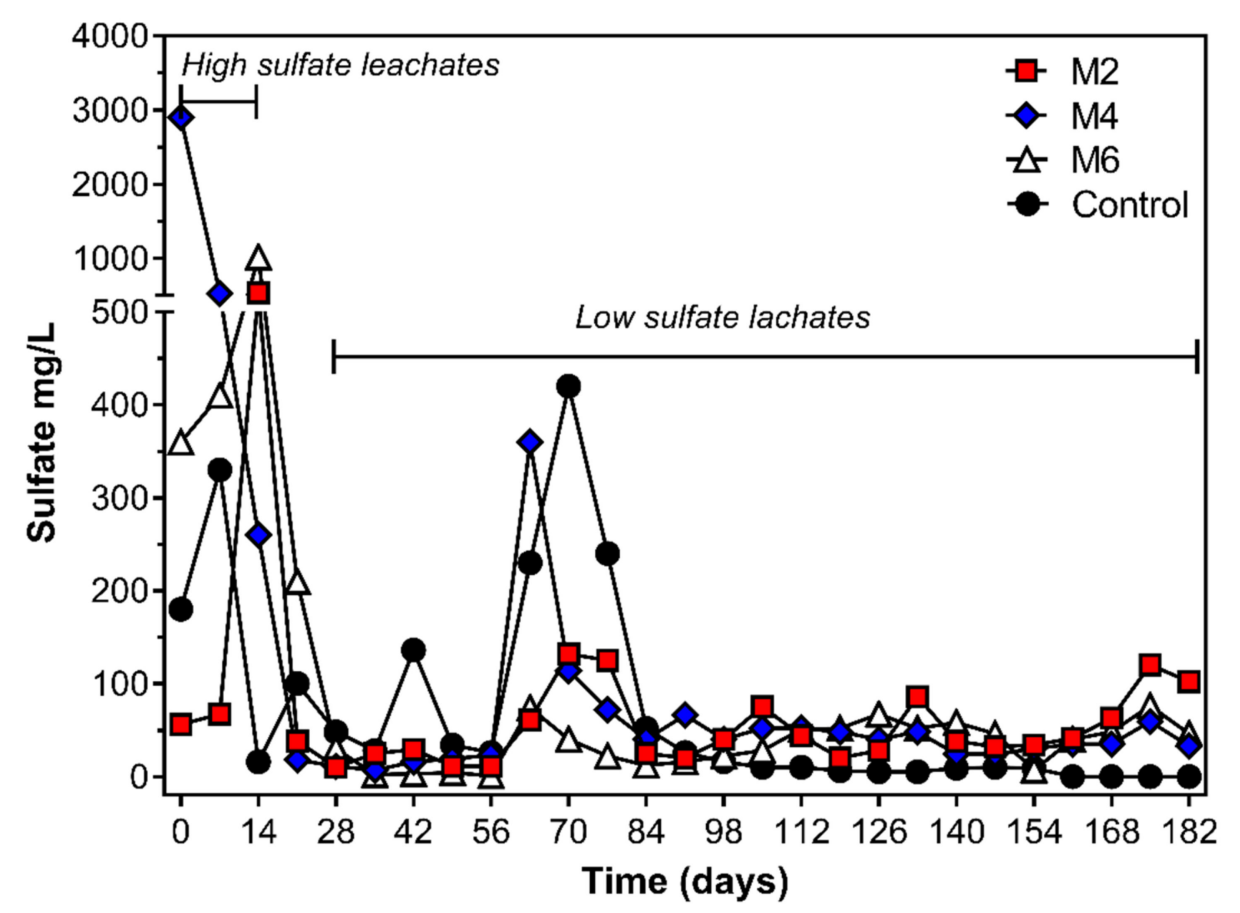

Figure 4. Sulfate evolution over time in the humidity cells tests for paste-tailing samples.

The accelerated oxidation of sulfide minerals (as pyrite $\left.\left(\mathrm{FeS}_{2}\right)\right)$ produces sulfate release as a consequence of the exposure of these minerals to both oxygen and water [55-57]. Despite the presence of air and water when operating the cells, low concentrations of sulfate were released in the leachates after cycle 3 , suggesting that significant oxidation processes do not occur in tailings samples. The evolution of sulfates in the leachates over time is well correlated with the $\mathrm{pH}$ values of the leachates, supporting the idea that net acid generation processes were negligible after cycle 3 . Indeed, the sulfate concentrations released in the leachates can be strongly influenced by the sulfate concentrations present in the paste tailings in the thickener and not by acid generation processes due to oxidation of sulfide minerals. The main sulfide minerals in the system are pyrite $\left(\mathrm{FeS}_{2}\right)$, sphalerite $((\mathrm{Zn}, \mathrm{Fe}) \mathrm{S}))$, galena $(\mathrm{PbS})$, and chalcopyrite $\left(\mathrm{CuFeS}_{2}\right)$. Although several studies have shown that these mineral phases can generate AMD [58-64], the acidity and low concentrations of sulfate were not considerably high, suggesting that the conditions that allow the generation of acid runoffs are not favored in this system.

Further, the concentrations of $\mathrm{Fe}, \mathrm{Mn}, \mathrm{Al}, \mathrm{Cu}, \mathrm{Zn}$, and $\mathrm{Pb}$ were monitored in the leachates of the humidity cells. Releases of very low concentrations of $\mathrm{Cu}$ and Fe were observed (Figure $5 \mathrm{a}, \mathrm{b}$ ). The concentrations of both $\mathrm{Fe}$ and $\mathrm{Cu}$ on all tailings samples were usually below $100 \mathrm{ug} / \mathrm{L}$ for paste-tailing samples, indicating that the concentrations released from these metals were not significant. The release of other metals like $\mathrm{Mn}, \mathrm{Al}, \mathrm{Zn}$, and $\mathrm{Pb}$ was negligible following their content in solid samples (see Table 2). 


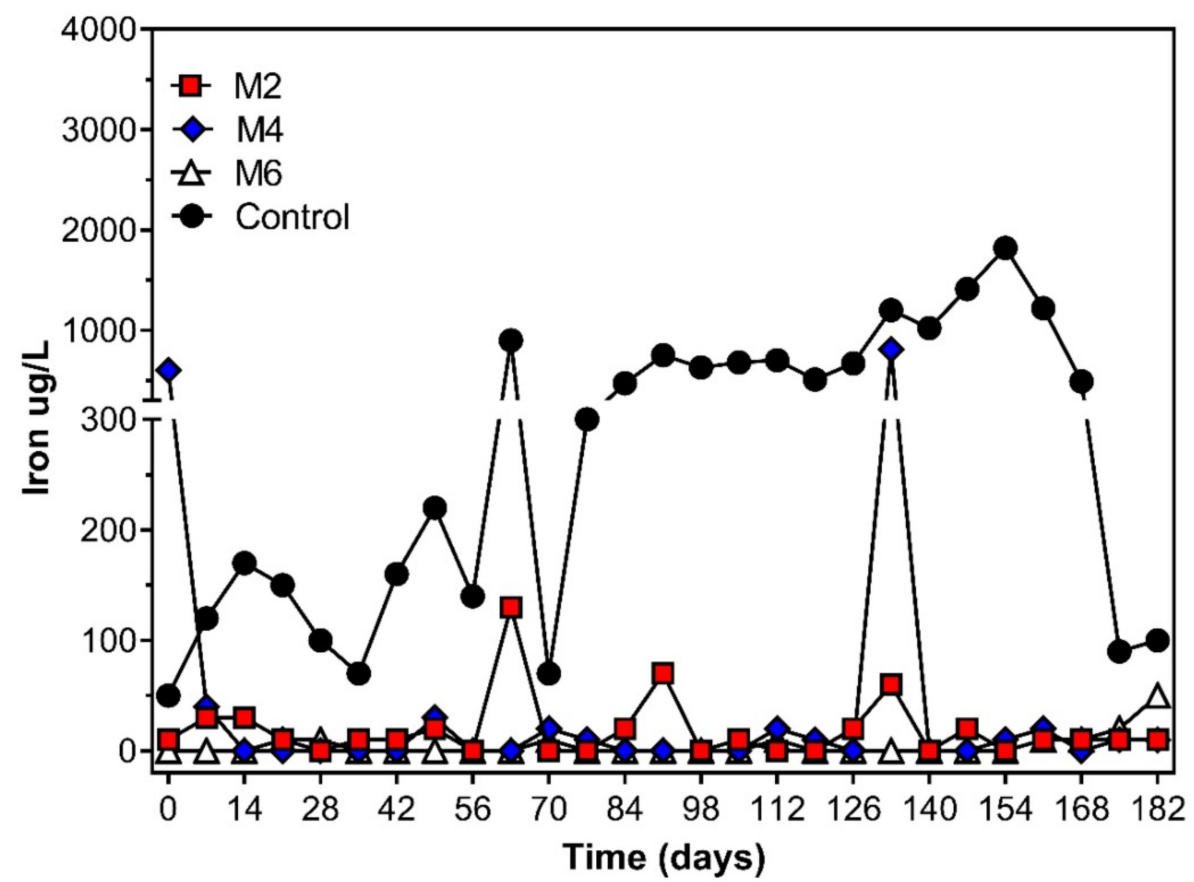

(a)

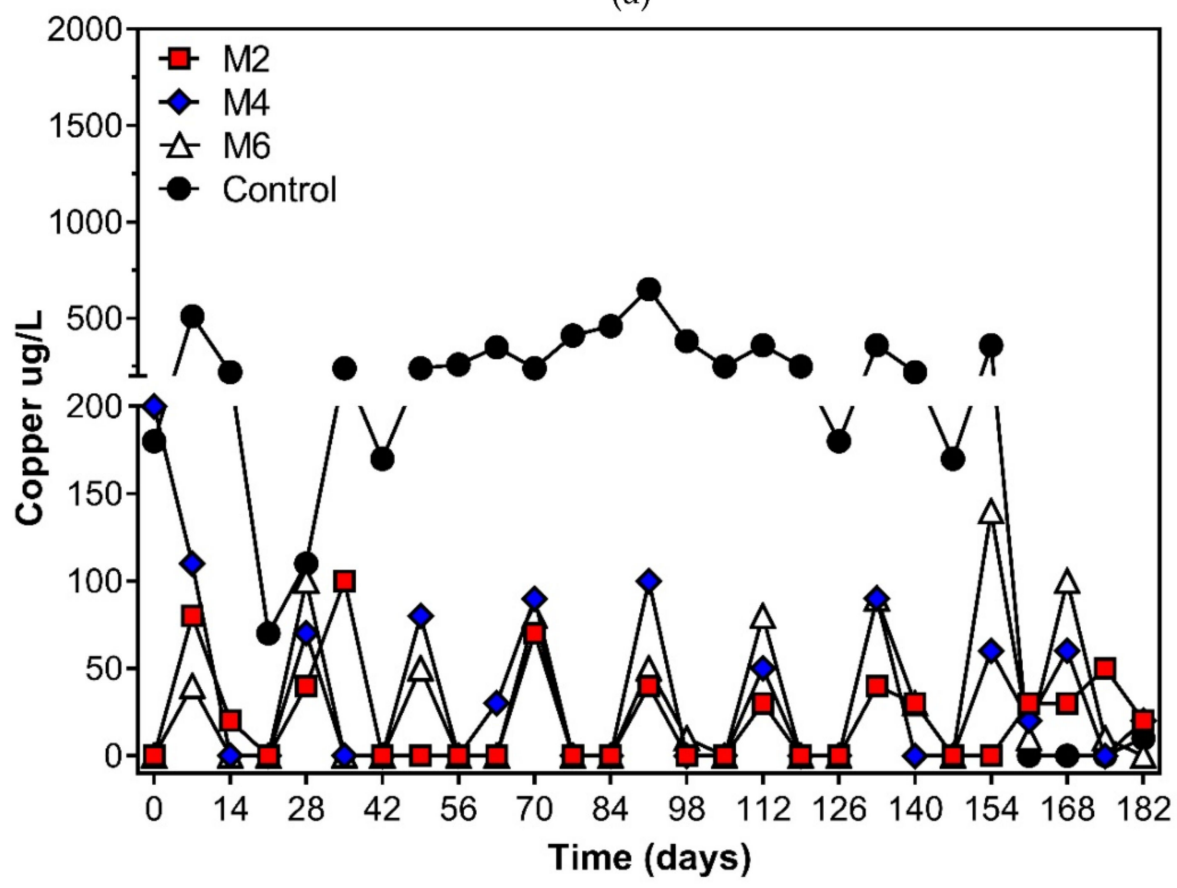

(b)

Figure 5. Dissolved iron (a) and dissolved copper (b) release over time in the humidity cells tests for paste-tailing samples.

Interestingly, the $\mathrm{Cu}$ values coincide with the solid phase analysis of tailing samples (see Table 2), where the $\mathrm{Cu}$ concentrations were below $595 \mathrm{ppm}$. In contrast, solid phase Fe concentrations reached values of $3.86 \mathrm{wt} \%$, suggesting that a higher concentration of iron could be released over time. Nevertheless, no significant Fe release was observed in leachates. In tailings, metal surface enrichment processes can occur by internal capillary forces that can lead to the mobilization of dissolved metals previously released to the tailings surface $[55,65]$. However, this was not observed in any sample, suggesting that the release of these metals as oxidation products was not significant over time. The 
low concentrations of heavy metals can be explained by the absence of AMD generation processes, which is supported by the absence of high rates of sulfate release as well as acid leachates. Even so, it may also be that the release kinetics was slower. The higher conductivity released in leachates during the first cycles (Figure 3) could be a consequence of this sample being taken from the secondary enrichment zone of the surface. This zone may have significant amounts of easily mobilized ions due to the high solubility of secondary minerals $[49,66,67]$. Nevertheless, there is no correlation between sulfate releases and heavy metal releases, indicating that this phenomenon may not be relevant for these samples.

It is evident that tailings samples eventually do not release acid leachates with a high metal load. However, high concentrations of sulfate in the pore water of paste tailings can generate changes in the viscosity of the paste, which may affect the consistency and self-containment capacity of the paste over time.

\subsection{Effective Cohesion of the Paste-Tailing Samples}

The determination of shear strength parameters (e.g., effective cohesion, $c^{\prime}$, and effective friction angle, $\left.\phi^{\prime}\right)$ is critical to assess the physical stability of geotechnical structures such as foundations, slopes, and retaining walls [68,69]. Moreover, $c^{\prime}$ and $\phi^{\prime}$ are the failure parameters defined through the envelope curve of maximal deviator stress [70]. However, there is little information on the impact or/and variation of these parameters in dams paste tailings. Here, the Mohr-Coulomb failure criterion was used to model and evaluate the failure envelope.

The obtained parameters of cohesion, friction angle, effective cohesion, and effective friction angle are shown in Table 3. To get these parameters, nine undrained triaxial monotonic compression tests were carried out with different confinement pressures $18 \mathrm{kPa}$ (1 test), $36 \mathrm{kPa}$ (1 test), $40 \mathrm{kPa}$ (1 test), $72 \mathrm{kPa}$ (4 tests), $80 \mathrm{kPa}$ (1 test), and $160 \mathrm{kPa}(1 \mathrm{test})$. The results from the analysis were $23^{\circ}$ and $2.9 \mathrm{kPa}$ for friction angle and cohesion, respectively. At the same time, the effective cohesion and the effective friction angle were $10^{\circ}$ and $6.9 \mathrm{kPa}$, respectively.

Table 3. Strength parameters of paste tailings.

\begin{tabular}{ccccc}
\hline Sample & $\begin{array}{c}\text { Friction Angle } \\
\boldsymbol{\varphi}_{\mathrm{T}}\left({ }^{\circ}\right)\end{array}$ & $\begin{array}{c}\text { Cohesion } \\
\mathbf{c}_{\mathbf{T}}(\mathbf{k P a})\end{array}$ & $\begin{array}{c}\text { Effective } \\
\text { Friction Angle } \\
\boldsymbol{\varphi}^{\prime}\left(^{\circ}\right)\end{array}$ & $\begin{array}{c}\text { Effective } \\
\text { Cohesion } \\
\mathbf{c}^{\prime}(\mathbf{k P a})\end{array}$ \\
\hline $\mathrm{A}$ & 23 & 2.9 & 10 & 6.9 \\
\hline
\end{tabular}

Studies using large-scale samples of waste rock from conventional tailings have found that typical values of $\phi^{\prime}$ range between $34^{\circ}$ and $45^{\circ}$, depending on the grain size distribution, material density, and other factors [71,72]. However, fully saturated paste typically has negligible $\phi^{\prime}$ (i.e., $\phi^{\prime}<5$ ). In the tailings samples from Florida gold mining, the values were higher, suggesting that these tailings lose their fully saturated state over time, likely by evaporation. This increases the solids percentage in the paste by decreasing the water content in surface areas. On the other hand, the value of the effective friction angle obtained for the tailings samples $\left(10^{\circ}\right)$ indicates that paste tailings exhibit low shear strength. Even this would give them lower stability compared to non-cohesive soils such as sand and gravel (that have $\phi^{\prime}>30^{\circ}$ values) [73].

Similarly, our results show that the cohesion and effective cohesion values are lower than for typical conventional tailings. Zhang et al. [74] found cohesion values between 14.7 and $27.6 \mathrm{kPa}$ and effective cohesion values between 11.64 and $25.07 \mathrm{kPa}$, considering coarse tailings, fine tailings, and the layered structure tailings collected from Pingchuan Iron Co., Ltd. in Yanyuan County, Sichuan Province, China. Moreover, Rankine and Sivakugan [75] reported that an increase in solids content resulted in a gain in the effective cohesion in cemented paste backfill from Cannington Mine, Australia. This supports the idea that the water content in paste tailings reduces cohesion forces for the tailings samples of Florida gold mining. Nevertheless, Pierce [76] reported that with high binder content and cure 
time, cohesion forces increases, and the friction angle is reduced. Our analyses indicate that Florida gold-mining operation generates paste tailings with a high load of agglomerating agents, explaining the low friction angles found on surface tailing samples. However, cohesion values do not follow this trend.

\subsection{Sulfate Content Effect on the Paste Consistency and Tailings Samples Strength}

To prove the impact of sulfate on the consistency of paste tailings, slump tests were performed with varying concentrations of sulfate $(0,500$, and $1000 \mathrm{mg} / \mathrm{L})$ to evaluate if sulfate concentrations affect this rheological factor. For this new paste, tailings were prepared by using the original tailing samples (solid phase).

The influence of the sulfate content of the paste on its consistency is shown in Figure 6. The results show that the slump test value is reduced as the sulfate concentration increases (Figure 6a). This effect is observed in all samples. Sample M4 shows the highest decrease in the slump test value, showing a reduction of $66 \%$ with a sulfate content of $1000 \mathrm{mg} / \mathrm{L}$. The decline in the consistency of paste tailings can be a consequence of the high sulfate concentrations. Figure $6 \mathrm{~b}$ shows a complete analysis of all the samples, showing that, with $500 \mathrm{mg} / \mathrm{L}$ of sulfate, the average of the slump test values reaches $59.9 \pm 0.08 \%$ of the original value (decrease of $\sim 40 \%$ ), while with $1000 \mathrm{mg} / \mathrm{L}$ of sulfate, the average of the slump test values reaches $45.3 \pm 0.09 \%$ of the original value (decrease of $~ 55 \%$ ). The analysis shows that the difference between 0 and $1000 \mathrm{mg} / \mathrm{L}$ for sulfate content in the paste tailing is statistically significant $(p<0.001)$ (Kruskal-Wallis and Dunn test) on the slump test values, which supports the impact that sulfate could have on the consistency of the paste tailings. Even so, low slump test values were observed $(<100 \mathrm{~mm})$, which may be a consequence of the high solids content of the original samples. In this area, the climate is semi-arid with high evaporation rates, which causes water loss on the surface of the tailings. As a result, this increases the solid content of the surface tailings samples. In addition, the downwards water flow due to gravity can also produce an increase in the percentage of solids. This makes the variation of the slump test value low.

It has been shown that the water content and the size distribution of the particles are important factors for a specific slump consistency. In fact, for a flowable paste, the particles must be finer than $20 \mathrm{um}$ and with a 15\% of solid ratio [77,78]. As shown in Figure 6, sulfate concentrations in the paste tailings could also impact the final consistency of the paste. Therefore, attention should be paid to this for the management of these tailings.

The water content (approximately $15-30 \% \mathrm{wt}$ ) in the preparation of paste tailings is important to ensure the adequate hydration of tailings samples and that the paste is properly formed $[47,79]$. In the paste, the charged colloidal electric particles can retain solid particles and water molecules, favoring their transport. However, the water content can also affect the consistency of paste tailings when it is in excess. The rheological properties of the paste (yield stress, viscosity, etc.) have been extensively studied to determine the palpability of the paste and to optimize the factors that affect the surface disposal of the paste and the consistency [14]. The mixed-water chemistry used to prepare the tailings paste has a marked impact on the rheological properties of the tailings and the internal cohesion forces of the paste tailings. This is a critical issue because one of the reasons by which paste tailings are employed is to eliminate the need to have a retaining wall, which is characteristic of conventional tailings dams. In the case of paste tailings, the role of the retaining wall is taken over by the thickened tailings, which are self-contained due to their own agglomeration. Nevertheless, a negative change in its consistency over time can progressively affect its self-contained capacity, generating hazardous events. 


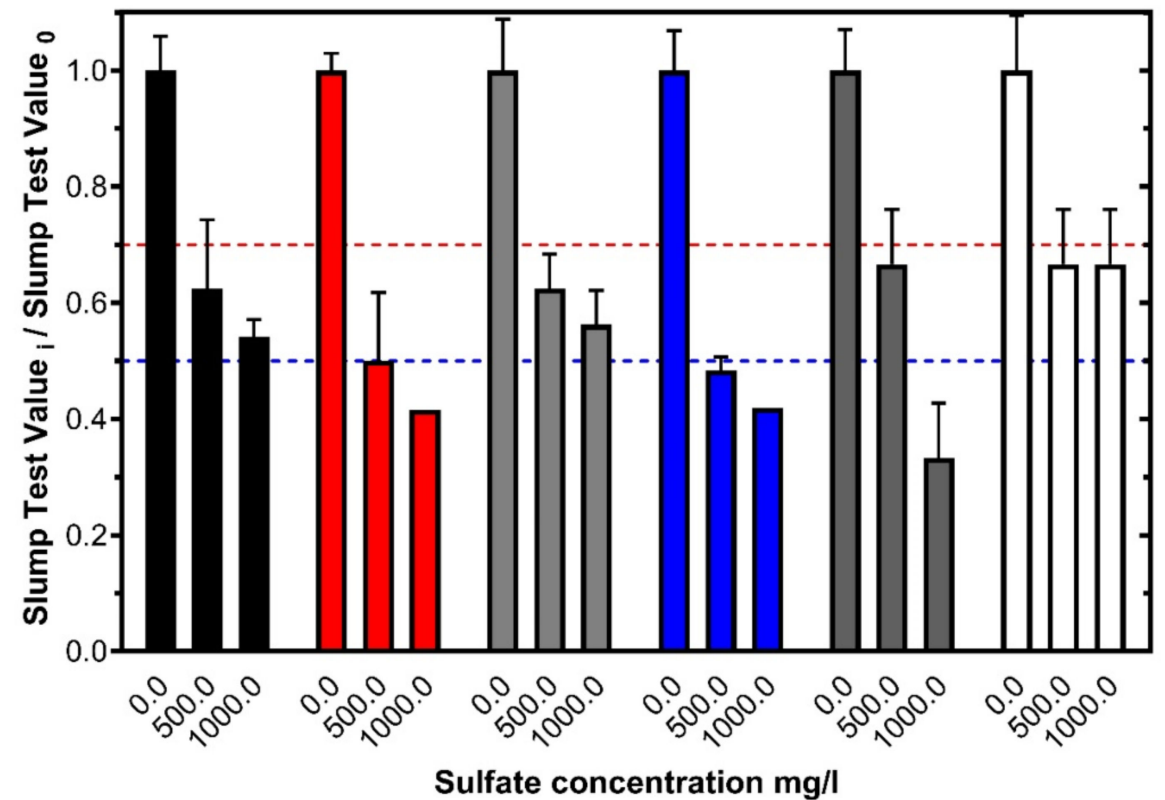

$\square \mathrm{M} 1 \square \mathrm{M} 2 \quad \square \mathrm{M} 3 \quad \square \mathrm{M} 4 \quad \square \mathrm{M} 5 \quad \square \mathrm{M} 6$

(a)

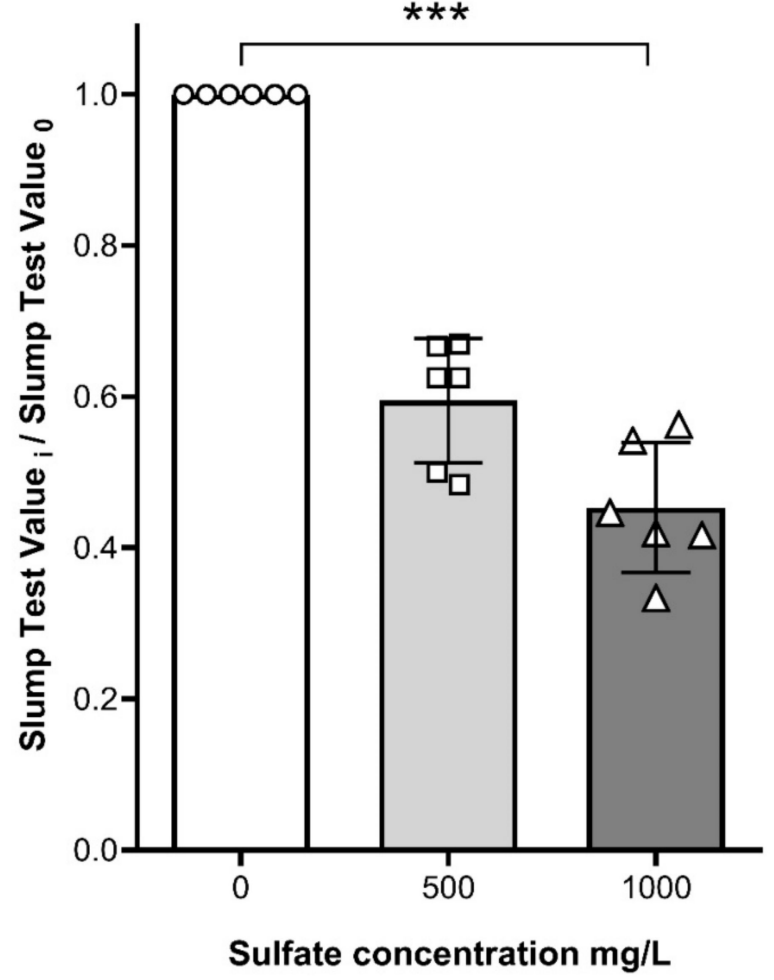

(b)

Figure 6. Effect of sulfate content on slump test values for individual (a) and grouped tailing samples $(\mathbf{a}, \mathbf{b})$. In $(\mathbf{b})$, percentages of difference $(\Delta-40 \%$ and $\Delta-55 \%)$ were calculated between the mean of the columns 500 and $1000 \mathrm{mg} / \mathrm{L}$ with the mean of slump test value at 0 sulfate concentration.

In paste applications, cohesion, density, and solid content (\%) are critical parameters [80]. Indeed, the cohesion of the paste particles could change according to the particle size distribution, binder quality, particle shape, and chemical resistivity [80]. Thus, changes 
in chemical reactivity could impact the stabilization of the paste tailings after storage. It has been observed that, in homogeneous and low-permeability paste, only thin layers are oxidized; however, changes in the internal reactivity of the tailings could change this, producing increases in the oxidation of sulfur minerals and the generation of AMD [80]. On the other hand, several researchers have shown that fractures or cracks in the surface of the tailings can produce alterations in permeability, which can favor internal oxidation processes [80-82]. Cracks or fractures in the surface of tailings occur mainly by two mechanisms; one is the consolidation that occurs due to the expulsion of moisture. The other is desiccation due to evaporation and cementing. In our case, the presence of sulfate is not directly associated with oxidation processes in the tailings, since no generation of acid leached with sulfate release was evident over time (Figure 4). Nevertheless, the paste tailing has high concentrations of free sulfate $(3854.5 \pm 1757.6 \mathrm{mg} / \mathrm{L}$ in the thickener), evidenced by the higher release of sulfate in the first cycles of operation of humidity cell.

All of these results allow us to establish an association between the chemical stability and consistency of the paste tailings with the sulfate content. Indeed, the presence of sulfate can have an undesirable impact on the paste tailings dams, which can change its self-containment capacity over time, being detrimental to the chemical stabilization of the paste tailings by creating a risk of generating polluting filtrations derived from AMD. The effect of sulfate could also favor the entry of oxygen and water, promoting oxidation processes of sulfur minerals inside the tailings and increasing the negative effect of sulfate over time. Thus, being able to control this parameter could be key to ensure the stability and sustainability of paste tailings dams and prevent the release of polluting filtrations that can be associated with an enhanced risk of physical stability.

\section{Conclusions}

The geochemical behavior of paste tailing was evaluated by using humidity cell tests. The results showed that paste tailings samples do not release acid leachates, because the $\mathrm{pH}$ in the leachates was mainly between 6 and 9 . The release of sulfate and dissolved metals $(\mathrm{Cu}$ and $\mathrm{Fe}$ ) was negligible after the first cycles of operation. Moreover, the release of leachate with high sulfate and EC during the first cycles of operation suggest that binders and reagents used in the paste tailing preparation have a high sulfate load. Undrained triaxial monotonic compression tests revealed that tailings samples have low cohesion strength $(2.9 \mathrm{kPa})$ and effective cohesion $(6.9 \mathrm{kPa})$, suggesting that the paste tailing consistency decreases over time due to water-mixed chemistry. In addition, tailings slurries prepared with water solutions with different sulfate concentrations $(0,500$, and $1000 \mathrm{mg} / \mathrm{L})$ showed that the slump test value decreases with higher sulfate content, thus negatively influencing the paste consistency.

Altogether, these results indicate that the initial sulfate content in the preparation of paste tailings is a crucial factor that must be necessarily considered for the optimization and operation of paste tailings dams.

Author Contributions: All authors collaborated in this work. The manuscript was written by E.L., but all the authors contributed to its preparation and review. E.L. and C.L. performed the design of the experiments and the discussion of results. Experiments and data analysis were performed by E.L., M.C. and L.D. Sampling was performed by M.T.; C.L. and E.L. reviewed and edited the manuscript. All authors have read and agreed to the published version of the manuscript.

Funding: This research was funded by the National Commission for Scientific and Technological Research (CONICYT) of Chile Primer concurso de investigación tecnológica en minería, del Fondo de Fomento al Desarrollo Científico y Tecnológico, FONDEF/CONICYT 2016 IT16M10012: 'Supervision and optimizing control of tailings using emergent technologies' and by FONDECYT DE INICIACIÓN 11191154 (2019-2022).

Institutional Review Board Statement: Not applicable.

Informed Consent Statement: Not applicable. 


\section{Data Availability Statement: Not applicable.}

Acknowledgments: We thank Marcelo Burstein Gray for his assistance in collecting tailings samples. We also extend acknowledgments to the reviewers for the corrections and suggestions, which contributed significantly to the improvement of the manuscript.

Conflicts of Interest: The authors declare no conflict of interest.

\section{References}

1. Gleisner, M. Quantification of Mineral Weathering Rates in Sulfidic Mine Tailings under Water-Saturated Conditions. Ph.D. Thesis, Institutionen för Geologi och Geokemi, Stockholms University, Stockholm, Sweden, 2005.

2. Kossoff, D.; Dubbin, W.E.; Alfredsson, M.; Edwards, S.J.; Macklin, M.G.; Hudson-Edwards, K.A. Mine tailings dams: Characteristics, failure, environmental impacts, and remediation. Appl. Geochem. 2014, 51, 229-245. [CrossRef]

3. Crowder, J.J. Deposition, Consolidation, and Strength of a Non-Plastic Tailings Paste for Surface Disposal. Ph.D. Thesis, Department of Civil Engineering, University of Toronto, Toronto, ON, Canada, 2004.

4. Newman, P.; White, R.; Cadden, A. Paste, the future of tailings disposal. In Proceedings of the 2nd International Conference on Mining and the Environment, Skelleftea, Sweden, June 25-July 1 2001; pp. 594-603.

5. Cincilla, W.A.; Landriault, D.A.; Verburg, R. Application of paste technology to surface disposal of mineral wastes. In Proceedings of the Fourth International Conference on Tailings and Mine Waste; A.A. Balkema: Brookfield, The Netherlands, 1997 ; pp. 343-356.

6. Henriquez, J.; Simms, P. Dynamic imaging and modelling of multilayer deposition of gold paste tailings. Miner. Eng. 2009, 22, 128-139. [CrossRef]

7. Brackebusch, F.; Shillabeer, J. Use of paste for tailings disposal. In Proceedings of the Sixth International Symposium on Mining with Backfill, The Australasian Institute of Mining and Metallurgy, Brisbane, Australia, 14-16 April 1998; pp. 53-58.

8. Newman, P.; Landriault, D. The Use of Paste Technology in the Surface Disposal of Mineral Waste; Waste Minimisation and Recycle Birmingham: Birmingham, UK, 1997.

9. Meggyes, T.; Debreczeni, A. Paste technology for tailings management. Land Contam. Reclam. 2006, 14, 815. [CrossRef]

10. Martin, V.; Aubertin, M.; McMullen, J. Surface disposal of paste tailings. In Proceedings of the 5th ICEG Environmental Geotechnics: Opportunities, Challenges and Responsibilities for Environmental Geotechnics; Thomas Telford Publishing: London, UK, 2006; Volume 2, pp. 1471-1478.

11. Nguyen, Q.D.; Boger, D.V. Application of rheology to solving tailings disposal problems. Int. J. Miner. Process. 1998, 54, 217-233. [CrossRef]

12. Benzaazoua, M.; Belem, T.; Bussiere, B. Chemical factors that influence the performance of mine sulphidic paste backfill. Cem. Concr. Res. 2002, 32, 1133-1144. [CrossRef]

13. Sofrá, F.; Boger, D.V. Environmental rheology for waste minimisation in the minerals industry. Chem. Eng. J. 2002, 86, 319-330. [CrossRef]

14. Kwak, M.; James, D.F.; Klein, K.A. Flow behaviour of tailings paste for surface disposal. Int. J. Miner. Process 2005, 77, 139-153. [CrossRef]

15. Pullum, L.; Graham, L.; Rudman, M.; Hamilton, R. High concentration suspension pumping. Miner. Eng. 2006, 19, 471-477. [CrossRef]

16. Sofrá, F. Rheological assessment-A road map for plant designers and operators. Paste 2006. In Proceedings of the Ninth International Seminar on Paste and Thickened Tailings; Australian Centre for Geomechanics: Crawley, Autralia, 2006; pp. 13-24.

17. Lamos, A.W.; Clark, I.H. The Influence of Material Composition and Sample Geometry on the Strength of Cemented Backfill. Innovation in Mining Backfill Technology; A.A. Balkema: Rotterdam, The Netherlands, 1989; pp. 89-94.

18. Ouellet, J.; Bidwell, T.J.; Servant, S. Physical and mechanical characterisation of paste backfill by laboratory and in-situ testing. In Proceedings of Minefill; Australasian Institute of Mining and Metallurgy: Carlton, Australia, 1998; pp. $249-254$.

19. Belem, T.; Benzaazoua, M.; Bussière, B. Mechanical behaviour of cemented paste backfill. In Proceedings of the 53rd Canadian Geotechnical Conference, Montreal, QC, Canada, 15-18 October 2000.

20. Blowes, D.W.; Ptacek, C.J.; Jambor, J.L.; Weisener, C.G. The Geochemistry of Acid Mine Drainage. In Treatise on Geochemistry; Elsevier Inc.: Amsterdam, The Netherlands, 2003; Volume 9, pp. 149-204. ISBN 9780080548074.

21. Naidu, G.; Ryu, S.; Thiruvenkatachari, R.; Choi, Y.; Jeong, S.; Vigneswaran, S. A critical review on remediation, reuse, and resource recovery from acid mine drainage. Environ. Pollut. 2019, 247, 1110-1124. [CrossRef]

22. Kefeni, K.K.; Msagati, T.A.M.; Mamba, B.B. Acid mine drainage: Prevention, treatment options, and resource recovery: A review. J. Clean. Prod. 2017, 151, 475-493. [CrossRef]

23. Lawrence, C.D. The influence of binder type on sulfate resistance. Cem. Concr. Res. 1992, 22, 1047-1058. [CrossRef]

24. Aldhafeeri, Z.; Fall, M. Time and damage induced changes in the chemical reactivity of cemented paste backfill. J. Environ. Chem. Eng. 2016, 4, 4038-4049. [CrossRef]

25. Fall, M.; Benzaazoua, M. Modeling the effect of sulphate on strength development of paste backfill and binder mixture optimization. Cem. Concr. Res. 2005, 35, 301-314. [CrossRef]

26. Fall, M.; Pokharel, M. Coupled effects of sulphate and temperature on the strength development of cemented tailings backfills: Portland cement-paste backfill. Cem. Concr. Compos. 2010, 32, 819-828. [CrossRef] 
27. Liu, L.; Zhu, C.; Qi, C.; Zhang, B.; Song, K.I. A microstructural hydration model for cemented paste backfill considering internal sulfate attacks. Constr. Build. Mater. 2019, 211, 99-108. [CrossRef]

28. Wang, Y.; Cao, Y.; Cui, L.; Si, Z.; Wang, H. Effect of external sulfate attack on the mechanical behavior of cemented paste backfill. Constr. Build. Mater. 2020, 263, 120968. [CrossRef]

29. Cui, B.; Liu, Y.; Feng, G.; Bai, J.; Du, X.; Wang, C.; Wang, H. Experimental study on the effect of fly ash content in cemented paste backfill on its anti-sulfate erosion. Int. J. Green Energy 2020, 17, 730-774. [CrossRef]

30. ASTM Standard test method for particle-size analysis of soils D 422-63. In Annual Book of ASTM Standards 04.08:117-127; American Society for Testing and Materials: West Conshohocken, PA, USA, 1972.

31. USEPA. Method 3050B. Acid digestion of sediments, sludges, and soils. In Test Methods for Evaluating Solid Waste; USEPA: Washington, DC, USA, 1996.

32. Sobek, A.A. Field and Laboratory Methods Applicable to Overburdens and Minesoils; Industrial Environmental Research Laboratory, Office of Research and Development, US Environmental Protection Agency: Washington, DC, USA, 1978.

33. ASTM. Standard Test Method for Accelerated Weathering of Solid Materials Using a Modified Humidity Cell; American Society for Testing and Materials: Washington, DC, USA, 1996; p. 13.

34. Lawrence, R.E. Laboratory procedures for the prediction of long term weathering characteristics of mining wastes. In Proceedings of Symposium on Acid Mine Drainage; Annual Meeting Geological Association Canada and Mineralogical Association; VCH: Vancouver, BC, Canada, 1990.

35. Price, W.A. Draft Guidelines and Recommended Methods for the Prediction of Metal Leaching and Acid Rock Drainage at Minesites in British Columbia; British Columbia Ministry of Employment and Investment, Energy and Minerals Division: Smithers, BC, Canada, 1997.

36. White, W.W., III; Lapakko, K.A. Preliminary indications of repeatability and reproducibility of the ASTM 5744-96 kinetic test for drainage $\mathrm{pH}$ and sulfate release rate. In Proceedings of the 5th International Conference on Acid Rock Drainage, Denver, CO, USA, 21-24 May 2000; pp. 621-630.

37. ASTM. Standard Test Method for Consolidated Undrained Triaxial Compression Test for Cohesive Soils; American Society for Testing and Materials: Washigton, DC, USA, 2004.

38. Clayton, S.; Grice, T.G.; Boger, D.V. Analysis of the slump test for on-site yield stress measurement of mineral suspensions. Int. J. Min. Process. 2003, 70, 3-21. [CrossRef]

39. Gawu, S.K.; Fourie, A.B. Assessment of the modified slump test as a measure of the yield stress of high-density thickened tailings. Can. Geotech. J. 2004, 41, 39-47. [CrossRef]

40. Nielson, R.F.; Peterson, H.B. Treatment of Mine Tailings to Promote Vegetative Stabilisation; Agricultural Experiment Station: Logan, UT, USA, 1972.

41. Evangelou, V.P.; Zhang, Y.L. A review: Pyrite oxidation mechanisms and acid mine drainage prevention. Crit. Rev. Environ. Sci. Technol. 1995, 25, 141-199. [CrossRef]

42. Wild, A. Soil and the Environment: An Introduction; Cambridge University Press: Cambridge, UK, 1993.

43. Ji, Y.; Lu, Q.; Liu, Q.; Zeng, H. Effect of solution salinity on settling of mineral tailings by polymer flocculants. Colloids Surf. A Physicochem. Eng. Asp. 2013, 430, 29-38. [CrossRef]

44. Ahmari, S.; Zhang, L. Durability and leaching behavior of mine tailings-based geopolymer bricks. Constr. Build. Mater. 2013, 44, 743-750. [CrossRef]

45. Gao, J.; Yu, Z.; Song, L.; Wang, T.; Wei, S. Durability of concrete exposed to sulfate attack under flexural loading and dryingwetting cycles. Constr. Build. Mater. 2013, 39, 33-38. [CrossRef]

46. Duchesne, J.; Fournier, B. Deterioration of Concrete by the Oxidation of Sulphide Minerals in the Aggregate. J. Civ. Eng. Arch. 2013, 7, 922-931. [CrossRef]

47. Deschamps, T.; Benzaazoua, M.; Bussière, B.; Aubertin, M.; Belem, T. Microstructural and geochemical evolution of paste tailings in surface disposal conditions. Miner. Eng. 2008, 21, 341-353. [CrossRef]

48. Fujiyasu, Y.; Fahey, M.; Newson, T. Field Investigation of Evaporation from Freshwater Tailings. J. Geotech. Geoenviron. Eng. 2000, 126, 556-567. [CrossRef]

49. Dold, B.; Fontboté, L. Element cycling and secondary mineralogy in porphyry copper tailings as a function of climate, primary mineralogy, and mineral processing. J. Geochem. Explor. 2001, 74, 3-55. [CrossRef]

50. Enkhzaya, S.; Ohe, K.; Shiomori, K.; Oyuntsetseg, B.; Bayanjargal, O.; Watanabe, M. Assessment of Heavy Metals in Mining Tailing Around Boroo and Zuunkharaa Gold Mining Areas of Mongolia. J. Environ. Sci. Technol. 2016, 9, 379-389. [CrossRef]

51. Cruz, R.; Bertrand, V.; Monroy, M.; González, I. Effect of sulfide impurities on the reactivity of pyrite and pyritic concentrates: A multi-tool approach. Appl. Geochem. 2001, 16, 803-819. [CrossRef]

52. Jerz, J.K.; Rimstidt, J. Pyrite oxidation in moist air. Geochim. Cosmochim. Acta 2004, 68, 701-714. [CrossRef]

53. Sapsford, D.; Bowell, R.; Dey, M.; Williams, K. Humidity cell tests for the prediction of acid rock drainage. Miner. Eng. 2009, 22, 25-36. [CrossRef]

54. Dold, B. Evolution of Acid Mine Drainage Formation in Sulphidic Mine Tailings. Minerals 2014, 4, 621-641. [CrossRef]

55. Dold, B. Acid rock drainage prediction: A critical review. J. Geochem. Explor. 2017, 172, 120-132. [CrossRef]

56. Johnson, D.B.; Hallberg, K.B. Acid mine drainage remediation options: A review. Sci. Total Environ. 2005, 338, 3-14. [CrossRef] [PubMed] 
57. Tabelin, C.B.; Corpuz, R.D.; Igarashi, T.; Villacorte-Tabelin, M.; Alorro, R.D.; Yoo, K.; Raval, S.; Ito, M.; Hiroyoshi, N. Acid mine drainage formation and arsenic mobility under strongly acidic conditions: Importance of soluble phases, iron oxyhydroxides/oxides and nature of oxidation layer on pyrite. J. Hazard. Mater. 2020, 399, 122844. [CrossRef]

58. Mafra, C.; Bouzahzah, H.; Stamenov, L.; Gaydardzhiev, S. Insights on the effect of pyrite liberation degree upon the acid mine drainage potential of sulfide flotation tailings. Appl. Geochem. 2020, 123, 104774. [CrossRef]

59. Ódri, Á.; Becker, M.; Broadhurst, J.; Harrison, S.T.L.; Edraki, M. Stable Isotope Imprints during Pyrite Leaching: Implications for Acid Rock Drainage Characterization. Minerals 2020, 10, 982. [CrossRef]

60. Chopard, A.; Plante, B.; Benzaazoua, M.; Bouzahzah, H.; Marion, P. Geochemical investigation of the galvanic effects during oxidation of pyrite and base-metals sulfides. Chemosphere 2017, 166, 281-291. [CrossRef]

61. Yang, B.; Luo, W.; Wang, X.; Yu, S.; Gan, M.; Wang, J.; Liu, X.; Qiu, G. The use of biochar for controlling acid mine drainage through the inhibition of chalcopyrite biodissolution. Sci. Total Environ. 2020, 737, 139485. [CrossRef]

62. Bao, Z.; Al, T.; Couillard, M.; Poirier, G.; Bain, J.; Shrimpton, H.K.; Finfrock, Y.Z.; Lanzirotti, A.; Paktunc, D.; Saurette, E.; et al. A cross scale investigation of galena oxidation and controls on mobilization of lead in mine waste rock. J. Hazard. Mater. 2021, 412, 125130. [CrossRef]

63. Liao, R.; Yang, B.; Huang, X.; Hong, M.; Yu, S.; Liu, S.; Wang, J.; Qiu, G. Combined effect of silver ion and pyrite on AMD formation generated by chalcopyrite bio-dissolution. Chemosphere 2021, 279, 130516. [CrossRef] [PubMed]

64. Murray, J.; Nordstrom, D.K.; Dold, B.; Kirschbaum, A. Seasonal fluctuations and geochemical modeling of acid mine drainage in the semi-arid Puna region: The Pan de Azúcar Pb-Ag-Zn mine, Argentina. J. S. Am. Earth Sci. 2021, 109, 103197. [CrossRef]

65. Olyphant, G.A.; Bayless, E.R.; Harper, D. Seasonal and weather-related controls on solute concentrations and acid drainage from a pyritic coal-refuse deposit in southwestern Indiana, U.S.A. J. Contam. Hydrol. 1991, 7, 219-236. [CrossRef]

66. Nordstrom, D.K.; Alpers, C.N. Negative $\mathrm{pH}$, efflorescent mineralogy, and consequences for environmental restoration at the Iron Mountain Superfund site, California. Proc. Natl. Acad. Sci. USA 1999, 96, 3455-3462. [CrossRef] [PubMed]

67. Bigham, J.M.; Nordstrom, D.K. Iron and aluminum hydroxysulfates from acid sulfate waters. Rev. Miner. Geochem. 2000, 40, 351-403.

68. Hawley, P.M. Site selection, characterization, and assessment. In Slope Stability in Surface Mining; Society for Mining, Metallurgy, and Exploration, Inc.: Littleton, CO, USA, 2001; pp. 267-274.

69. Holtz, R.D.; Kovacs, W.D. An Introduction to Geotechnical Engineering; Pearson Education: Taipei, Taiwan, 2003; 733p.

70. Wang, Y.; Akeju, O.V. Quantifying the cross-correlation between effective cohesion and friction angle of soil from limited site-specific data. Soils Found. 2016, 56, 1055-1070. [CrossRef]

71. McLemore, V.T.; Fakhimi, A.; van Zyl, D.; Ayakwah, G.F.; Anim, K.; Boakye, K.; Ennin, F.; Felli, P.; Fredlund, D.; Gutierrez, L.; et al. Literature Review of Other Rock Piles: Characterization, Weathering, and Stability. Questa Rock Pile Weathering Stability Project; New Mexico Bureau of Geology and Mineral Resources: Socorro, NM, USA, 2009; p. 101.

72. Aubertin, M. Waste rock disposal to improve the geotechnical and geochemical stability of piles. In Proceedings of the World Mining Congress, Montreal, QC, Canada, 11-15 August 2013.

73. Das, B.M.; Sobhan, K. Principles of Geotechnical Engineering, 7th ed.; Cengage Learning: Stanford, CA, USA, 2010.

74. Zhang, Q.; Yin, G.; Wei, Z.; Fan, X.; Wang, W.; Nie, W. An experimental study of the mechanical features of layered structures in dam tailings from macroscopic and microscopic points of view. Eng. Geol. 2015, 195, 142-154.

75. Rankine, R.M.; Sivakugan, N. Geotechnical properties of cemented paste backfill from Cannington Mine, Australia. Geotech. Geol. Eng. 2007, 25, 383-393.

76. Pierce, M.E. Laboratory and Numerical Analysis of the Strength and Deformation Behavior of Paste Backfill. Master's Thesis, Queens University, Kingston, ON, Canada, 1997.

77. Verburg, R.B. Use of paste technology for tailings disposal: Potential environmental benefits and requirements for geochemical characterization. IMWA Symp. 2001, 2001, 13.

78. Kesimal, A.; Erçikdi, B.; Yilmaz, E. The effect of desliming by sedimentation on paste backfill performance. Miner. Eng. 2003, 16, 1009-1011.

79. Deschamps, T.; Benzaazoua, M.; Bussière, B.; Aubertin, M. Laboratory study of surface paste disposal for sulfidic tailings: Physical model testing. Miner. Eng. 2011, 24, 794-806. [CrossRef]

80. Yilmaz, E.; Benzaazoua, M.; Bussière, B.; Pouliot, S. Influence of disposal configurations on hydrogeological behaviour of sulphidic paste tailings: A field experimental study. Int. J. Miner. Process. 2014, 131, 12-25. [CrossRef]

81. Theriault, J.; Frostiak, J.; Welch, D. Surface disposal of paste tailings at the Bulyanhulu gold mine. In Proceedings of the 2nd Mining Environment Conference, Sudbury, ON, Canada, 25-28 May 2003; pp. 1-8.

82. Simms, P.; Grabinsky, M.W.; Zhan, G. Modelling evaporation of paste tailings from the Bulyanhulu mine. Can. Geotech. J. 2007, 44, 1417-1432. [CrossRef] 